\title{
Corrigendum: Skills required for the management of Black-owned small enterprises in Soweto
}

\begin{abstract}
Authors:
Ellen Nkosi ${ }^{1}$

Maria Bounds

Adele Thomas ${ }^{2}$

Geoff Goldman
\end{abstract}

\section{Affiliations:}

${ }^{1}$ Department of Business

Management, University of

Johannesburg, South Africa

${ }^{2}$ Industrial Psychology and People Management, University of Johannesburg South Africa

Correspondence to:

Maria Bounds

Email:

mbounds@uj.ac.za

Postal address:

PO Box 524, Auckland Park

2006, South Africa

Dates:

Published: 17 Dec. 2015

How to cite this article:

Nkosi, E., Boun., M., Thomas,

A. \& Goldman, G., 2015

'Corrigendum: Skills required

for the management of Black-

owned small enterprises in

Soweto', Acta Commercii

13(1), Art. \#186, 1 pages.

http://dx.doi.org/10.4102/

ac.v13i1.186-2

Note:

Doi of original article:

http://dx.doi.org/10.4102/

ac.v13i1.186

\section{Copyright:}

(C) 2015. The Authors.

Licensee: AOSIS

OpenJournals. This work is

licensed under the Creative

Commons Attribution

License.

Read online:

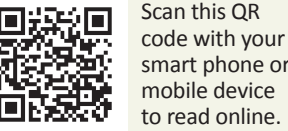

The authors apologise for providing the incorrect department for second affiliation. It has been changed from Industrial Relations and People Management to Industrial Psychology and People Management under the affiliation section. In addition the Author contributions were also updated. Please see below.

\section{Author Contributions}

E.Y.N. (University of Johannesburg) conducted the research as an M. Com Business Management student, with M.M.B. (University of Johannesburg) as supervisor and A.T (University of Johannesburg) as co-supervisor. The manuscript was drafted by E.Y.N. G.G. (University of Johannesburg) and M.M.B. reworked the manuscript into its final form. 


\section{Corrigendum: Skills required for the management of Black-owned small enterprises in Soweto}

\begin{abstract}
Authors:
Ellen Nkosi ${ }^{1}$

Maria Bounds

Adele Thomas ${ }^{2}$

Geoff Goldman
\end{abstract}

\section{Affiliations:}

${ }^{1}$ Department of Business

Management, University of

Johannesburg, South Africa

${ }^{2}$ Department of Industrial

Relations and People

Management, University of

Johannesburg

Correspondence to:

Maria Bounds

\section{Email:}

mbounds@uj.ac.za

Postal address:

PO Box 524, Auckland Park

2006, South Africa

\section{Dates:}

Published: 28 Oct. 2015

How to cite this article:

Nkosi, E., Bounds. M.

Thomas, A. \& Goldman, G.,

2013, 'Corrigendum: Skills

required for the management

of Black-owned small

enterprises in Soweto',

Acta Commercii 13(1), Art.

\#186, 1 pages. http://dx.doi.

org/10.4102/ac.v13i1.186-1

\section{Note:}

Doi of original article:

http://dx.doi.org/10.4102/

ac.v13i1.186

\section{Copyright:}

(C) 2015. The Authors

Licensee: AOSIS

OpenJournals. This work is

licensed under the Creative

Commons Attribution

License.

Read online:

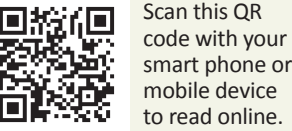

The authors apologise for omitting the third author's name of their article, Skills required for the management of Black-owned small enterprises in Soweto, published 15 Augustus 2015.

Author Adele Thomas, has now been added to this article under the 'Authors' section. 


\section{Skills required for the management of Black-owned small enterprises in Soweto}

\author{
Authors: \\ Ellen Nkosi ${ }^{1}$ \\ Maria Bounds ${ }^{1}$ \\ Geoff Goldman \\ Affiliations: \\ ${ }^{1}$ Department of Business \\ Management, University of \\ Johannesburg, South Africa \\ Correspondence to: \\ Maria Bounds \\ Email: \\ mbounds@uj.ac.za \\ Postal address: \\ PO Box 524, Auckland Park, \\ 2006 \\ Dates: \\ Received: 13 Mar. 2013 \\ Accepted: 29 May 2013 \\ Published: 15 Aug. 2013 \\ How to cite this article: \\ Nkosi, E., Bounds. M. \\ \& Goldman, G., 2013, \\ 'Skills required for the \\ management of Black- \\ owned small enterprises in \\ Soweto ', Acta Commercii \\ 13(1), Art. \#186, 10 pages. \\ http://dx.doi.org/10.4102/ \\ ac.v13i1.186

\section{Copyright:} \\ (C) 2013. The Authors. \\ Licensee: AOSIS \\ OpenJournals. This work \\ is licensed under the \\ Creative Commons \\ Attribution License.
}

Read online:
Orientation: This study sought to identify which business and management skills are present amongst Black small-business owners in Soweto, as small businesses are not always aware of the skills needed in order to be successful in business endeavours.

Research purpose: The purpose of the study was to identify the most pertinent business and management skills required for the management of small enterprises in Soweto.

Motivation for the study: Small-business creation is viewed as being a major contributor to economic growth. The motivation of the study was to foster understanding with regard to which business and management skills are essential to the longevity of a small business and to foster growth in small-business creation.

Research design, approach and method: A qualitative survey was conducted amongst 25 Black-owned small enterprises in Soweto. Data were gathered by means of semi-structured interviews. Content analysis, using literature as basis for common themes forthcoming from the interviews, was employed as the means of data analysis.

Main findings: The findings indicated that most enterprise owners lack management and business skills, that there is no single key success factor in managing small enterprises, that competitive advantage is seemingly overlooked and that small-enterprise owners seem to be driven by non-monetary rewards.

Practical/managerial implications: The study affirmed that a contextualised approach to management is crucial, irrespective of the scope of the business and that strategy is considered in a different light in a small business.

Contribution/value-add: Although the findings did not suggest anything contrary to the literature relating to skills, they did highlight the uniqueness of strategic management aspects in small enterprises and also alluded to the communal outlook of Black small-enterprise owners.

\section{Introduction}

Small enterprises deliver a marked contribution to the economy of a country. In this regard, Papulová and Mokroš (2007) state that small enterprises in the European Union are the engine for societal development as, apart from the obvious contributions they make toward the gross domestic profit (GDP), they are, inter alia, a source of employment and training for the youth. Tambunan (2007) noted that small enterprises in Indonesia account for $90 \%$ of firms outside the agricultural sector and are the biggest providers of jobs in the country. In Vietnam, small enterprises are also regarded as being dynamic forces that contribute to job creation (Tuan \& Yoshi 2009). Foreman-Peck, Makepeace and Morgan (2006) state that small enterprises contribute to $55.4 \%$ of employment opportunities in the United Kingdom. In India, small enterprises are known as Small-Scale Industries (SSI) and contribute 39\% of the gross industrial value-add and account for 35\% of the total exports to the Indian economy (Bodla \& Verma 2008). The Smalland Medium-Enterprise (SME) Development Council of Malaysia (2010) states that in Malaysia, between 2004 and 2009, small enterprises outperformed the overall economy in terms of valueadded growth, at a rate of $6.3 \%$ compared with $4.5 \%$ for overall GDP growth. The scenario sketched above underscores the important role small enterprises play in the economy of a nation.

In South Africa, according to Abor and Quartey (2010), small- and medium enterprises are seen as a significant way of creating employment. These businesses have the ability to ensure an equitable distribution of income, promote general economic welfare amongst all citizens, improve the local market and make productive use of scare resources. Consequently, they enhance long-term economic growth within the country. 
In spite of this contribution to the economy, small enterprises exhibit high failure rates soon after start up (Moodie 2003). Van Eeden, Viviers and Venter (2003) reported that up to $80 \%$ of South African small-business ventures fail within five years of establishment. Giliomee (2004) adds that of the $20 \%$ that survive for longer than five years, a further $80 \%$ fail within the next five years. This implies that only $4 \%$ of business ventures will survive beyond 10 years. This situation is not unique to South Africa, as $80 \%$ of business ventures started in 2000 and 2001 in the USA went out of business within five years (Papulová \& Mokroš 2007). The main reasons for this high failure rate seem to centre on insufficient business skills on the part of the person or group that initiates the business venture.

Prior to 1994, historically Black-inhabited townships were typified by small, informal subsistence-orientated businesses that offered basic products to low-income earners (Ligthelm 2009). Most Soweto residents used the Central Business District (CBD) and surrounding shopping malls to do their shopping. In the wake of the political- and social change experienced in South Africa, many informal small businesses started registering and complying with the existing labour legislation. More malls were developed in historically Black areas in order to tap into the buying potential of the Black market, which provided an opportunity both for large retailers to expand into these areas and for small enterprises to grow and compete with the more established players (Ligthelm 2009).

Given their background, Black small-enterprise owners might not have had the educational and training opportunities as small-enterprise owners from other racial backgrounds and it is possible that 'street smarts', as opposed to education, could have contributed greatly to the development of their enterprises. This study focused on whether Black smallenterprise owners reflect the literature in terms of the business- and management skills required for the success of a small enterprise.

\section{Literature review}

Management skills, in the form of conceptual- and interpersonal skills, are abstract and cannot be learned, unlike business skills, which are operational and can be acquired through learning. Business- and management skills, therefore, complement each other in the management of small enterprises (Pettinger 2007).

As already mentioned, the main contributing factor to the failure of new business ventures is a lack of appropriate business skills in the owner(s) of the new endeavour. It would therefore be appropriate to interrogate the aspect of business skills in more detail. 'Business skills', simply put, is a collective term that encompasses the several skills that are necessary in order to run a business efficiently and effectively. In this regard, Strydom (2005) lists the following business skills, in order of priority, as being essential for small enterprises: marketing skills, financial skills and purchasing or procurement skills. Marx, Van Rooyen and Reynerder (1998), on the other hand, also mention marketing skills and financial skills, but add both legal- and entrepreneurial skills to the list. Marx et al. (1998) argue that of all the business skills described in the literature, marketing skills, financial skills, legal skills and entrepreneurial skills are the basic business skills necessary in order for a small enterprise to survive.

In a survey conducted in 2005 amongst business owners in Mamelodi, marketing- and financial skills were rated as being the critical skills needed by small enterprises (Strydom 2005). Sixty-three per cent of respondents in this survey identified training in marketing skills as being an area of urgent training need for small enterprises and $71 \%$ identified bookkeeping skills as another such urgent need (Strydom 2005).

\section{Business- and management skills required in a successful small enterprise}

From the discussion above, marketing-, financial-, legal- and entrepreneurial skills seem to be the most salient business skills required for the success and longevity of a small enterprise. These will now be dealt with in more detail.

\section{Marketing skills}

Needle (2004) describes marketing management as an interactive process aimed at satisfying or exceeding customers' needs. It is this interactive process of satisfying customers' needs that enables small enterprises to exist and grow, even in difficult times. Meggison, Byrd and Meggison (2006) argue that marketing skills not only satisfy customers' needs, but also help owners to make satisfactory profits. Nieman (2006) adds that an enterprise cannot be viable if it cannot sell its services or products.

There are other effects of marketing skills. These include a deeper understanding of customer needs and behaviour as well as of the marketplace, which results in effective marketing strategy (Needle 2004). A business owner who has marketing skills realises the importance of relationship marketing. This means that the owner focuses on maintaining good long-term relationships with customers and suppliers and, in return, benefits by retaining both (Hatten 2009).

\section{Financial skills}

Collis and Jarvis (2002) state that financial skills are essential for the growth and success of small enterprises. They describe financial skills as being the control and monitoring of the performance of an enterprise using management accounts and cash-flow information. Needle (2004) describes financial skills as being part of the finance and accounting tasks that deal with the raising of capital to finance the enterprise. Nieman (2006) describes financial skills as the skills that are responsible for ensuring that the enterprise makes the best use of its financial resources. 
Lee and McGuiggan (2008) identified financial skills which are important to small-enterprise owners, such as benchmarking business performance, analysing and forecasting cash flows, facilitating online transactions, managing retirement funds, understanding business exit strategies, pricing of goods and services and investment decisions. Owners with sound financial skills are able to use the information at their disposal in order to predict and plan their costs and income and make suitable decisions that will increase profitability and satisfy their customers' needs (Burgess 2007).

The adoption of sound financial management practices impacts on the performance of small enterprises (Gloy \& LaDue 2003). Burgess (2007) supports this view by noting that most managers are good at customer care but lack financial skills, resulting in overall ineffectiveness in their jobs and impacting negatively on profitability. Oosthuizen and Van Tonder (2010) also state that it is important for small-enterprise owners to choose the most appropriate finance option that suits their business needs, which can be done if the owners have sound financial skills.

\section{Legal skills}

According to Hatten (2009), small-enterprise owners need legal skills so as to ensure that their businesses are functioning within the boundaries of what is permissible legally. Hatten (2009) further argues that small-enterprise owners do not need a law degree, but that they must have a working knowledge of legal basics. It is therefore imperative that a small-enterprise owner possess a working knowledge of the basics of the labour laws of the country (Van Rensburg 2008).

Legal skills are of importance to small enterprises in order to ensure that owners are aware of issues relating to litigation that could be harmful to the business should the small enterprise not comply with the law. In trying to comply with the law, enterprise owners are, however, faced with challenges. According to Hatten (2009), the following are some of the challenges that small-enterprise owners experience:

- Legal wording is technical and not easy to understand.

- Legal documents often imply vast amounts of paperwork and the small enterprise owner can get lost and confused with the detail.

Meggison et al. (2006) state that the first thing small-enterprise owners should do when contemplating a new business venture is to seek the advice of an experienced lawyer. Hatten (2009) supports this view by noting that enterprise owners must engage the services of a lawyer at the time that they are drafting their business plans and not when they are already in trouble.

\section{Entrepreneurial skills}

Nieuwenhuizen (2008) describes entrepreneurial skills as being skills that are conveyed by a person's behaviour and are linked to personal- and interpersonal capabilities.
There are three groups of competencies associated with entrepreneurial skills: pro-activeness, achievement orientation and commitment to others.

Entrepreneurship is associated with innovation and this is an important aspect in managing an enterprise. Entrepreneurial characteristics such as commitment and determination, leadership, opportunity obsession and motivation to excel, are important for the successful management of small enterprises. Persistence and determination are estimated to make a contribution to over $90 \%$ of small-business successes (Bateman \& Snell 2009).

\section{Management skills required to manage small enterprises}

According to Dockel and Ligthelm (2005), management is a crucial factor in determining business growth. On this issue, they state that '... management acumen is indispensable for running successful small enterprises' (2005:61).

Bekele and Worku (2008) state that in enterprises where owners possess sound managerial skills, the enterprises stand a better chance of longevity. Nieman and Bennett (2006), as well as Pettinger (2007), identified three key managerial skills, namely conceptual-, interpersonal- and technical skills. Although these skills have been investigated more from a corporate point of view (Nieman \& Bennett 2006), their application can also be adopted by the small enterprise (Pettinger 2007). It is important to note that these skills differ depending on various identifiable managerial levels. In a corporate setting, top management would typically be required to apply, for example, more conceptual skills and fewer technical (or hands-on) skills. At a supervisory level, technical skills and conceptual skills (also referred to as strategic skills) would predominate. In the setting of the small enterprise, however, definite managerial levels often do not exit, hence the small-enterprise owner is often required to occupy multiple managerial roles, necessitating a balance of all these skills. This is because they are responsible for most, if not all, of the managerial functions in the enterprise.

In terms of conceptual skills, different authors mention that small enterprises can benefit from conceptual skills in the following ways:

- Conceptual skills help in developing plans, strategising and organising resources effectively (Marx et al. 1998).

- Small enterprises compete in a continuously-diversifying environment and conceptual skills help in understanding the enterprise and how it relates to the environment within which it operates (Nieman \& Bennett 2006).

- Owners with conceptual skills possess vision and, in general, have better problem-solving abilities (Northouse 2009).

As far as interpersonal skills are concerned, Robbins and Hunsaker (2006) have compiled a list of crucial interpersonal skills (see Table 1). They argue that the list comprises interpersonal skills that experts believe successful managers and future managers should possess. 
TABLE 1: Key interpersonal skills.

\begin{tabular}{ll}
\hline Listening & Self-awareness \\
\hline Sending messages & Persuading \\
Setting goals & Politicking \\
Providing feedback & Running meetings \\
Resolving conflicts & Negotiating \\
Managing change & Working with diverse groups of people \\
Coaching & Working with teams \\
Ethical decision making & Creative problem solving \\
\hline
\end{tabular}

Source: Robbins \& Hunsaker (2006:4)

Interpersonal skills benefit small enterprises in the following ways:

- They enable management of diversity, conflict and change and enable owners to lead, motivate and evaluate employee performance (Nieman \& Bennett 2006).

- They enable trust, coordination and planning (Robbins \& Hunsaker 2006).

- They empower owners with the ability to understand others and to know what motivates people (Bateman \& Snell 2009).

The success of an enterprise depends on a thorough knowledge of the product or service provided. Technical skills are needed in order to assess what is possible when a customer requests a personalised service or product. In terms of technical skills, Roodt (2005), Nieman and Bennett (2006) and Pettinger (2007) all state that service delivery and customer satisfaction are dependent upon superior technical skills. They also say that owners need to have technical skills in order to supervise employees and to assess whether they are performing tasks correctly. In addition, they should have the specific knowledge, techniques and resources required for the performance of all tasks in order to be successful at managing their enterprises.

Parmigiani and Mitchell (2010) also state that most enterprises focus on technical skills rather than on other expertise, as technical expertise is seen to contribute most to the performance of the enterprise. It should, however, be noted that technical skills on their own are not enough. Multiple skills, such as financial conceptual skills together with technical skills, are needed for the functioning of a successful enterprise (Roodt 2005). Davis and Woodward (2009) support this sentiment by noting that most employers not only look for technical skills, but also for strong 'soft' skills in order to have a competitive edge.

\section{Problem statement and objective}

The high failure rate of most small enterprises raises concerns, not only for the owners, but for the government as well, especially from an economic development point of view (Ligthelm 2008). This has resulted in the South African government prioritising small-business development programmes (Ligthelm 2008) which are meant to address some of the factors that contribute to the failures of small enterprises, such as lack of essential business- and management skills on the part of the business owner (Strydom 2005) and lack of investment in training. In this regard, Kotey and Folker (2007:216) stated that 'there is general reluctance among SMEs to provide formal employee training'. Another factor contributing to the failure of small enterprises is a lack of business knowledge, business skills and management skills when the founder is succeeded (Egbu, Hari \& Renukappa 2005).

The research problem thus seems to be that small enterprises that have been in business for a period of five years or more have done so because of the presence of certain skills required for the effective- and efficient management of small enterprises. However, these skills have seemingly not been articulated clearly for Black-owned South African small enterprises. This study, therefore, endeavours to identify which business- and management skills are present amongst Black small-business owners in Soweto.

\section{Research method and design}

The approach employed in this study was interpretive research using qualitative methods that focus specifically on words, descriptions and observations in order to gather data (Beins 2009; Bless, Higson-Smith \& Kagee 2006; Zikmund 2009). It is important to understand that one can only experience a particular reality through one's perceptions, which are, in turn, influenced by preconceived ideas and beliefs (Walliman 2006). That is to say, one does not take an external view of the world, instead one views it from within the situation that is being studied (Walliman 2006). The approach used in this study allowed for the collection of descriptive data with the intention of developing an understanding of business- and management skills required for the management of small enterprises in Soweto from within these enterprises being studied. This research approach thus attempts to understand the phenomena being studied through the meaning and interpretations that individuals assign to them.

As the study is aimed at investigating the management skills present in Black-owned small enterprises, it can also be viewed as being an ethnographic study. Ethnography produces findings derived from collecting data on the behaviour of (and in) a particular society (Babbie \& Mouton 2004). The cultural boundaries of this study (Black-owned small enterprises) define the parameters of the particular society (Soweto) within which the research will be conducted. Soweto has always been viewed as a city that takes the lead and where innovative approaches to things are sought in an active manner. This was the main motivation behind selecting Soweto as the target area for this study. A major challenge was that many business owners did not have formal business- or management education and therefore had their own ideas regarding what was necessary in order to keep the business enterprise as a going concern over a prolonged period of time.

The population for the study was compiled from lists of retailers in Soweto held by the Centre for Small Business Development at the University of Johannesburg, the Soweto Chamber of Commerce and from a Soweto Business Guide 
found on the Internet. Potential participants were contacted telephonically to ascertain how long they had been running their business and also to secure an appointment for an interview if they had indeed been in business for five years or more. Letters requesting permission to conduct interviews were then delivered to the participants as a means of obtaining written consent for participation in the study. Interviews were conducted in English, although there were some concepts or questions that were explained in IsiZulu or SeSotho by one of the researchers, who is proficient in English, IsiZulu and SeSotho. Approximately 300 retailers were contacted initially from the lists obtained. Of these small enterprises, 97 had been conducting business for a period of five years or longer. A sample of 25 Black-owned small enterprises was selected using a convenience, nonprobability sampling method. When selecting participants for qualitative studies, the only criterion is how relevant the participant is to the topic being researched (Neuman 2003).

Data were collected by means of semi-structured interviewing. This data collection method generates data through conversations with people concerning their dayto-day dealings and interactions with other people. The main function of the researcher during an interview is to provide a framework for the discussion as it unfolds (Miller \& Brewer 2003). For this study, topics emerging from the literature were employed so as to guide the semi-structured interviews. As the study sought to identify which businessand management skills were present amongst Black smallbusiness owners in Soweto, the interviews sought to solicit views pertaining to the most commonly-mentioned businessand management skills forthcoming from literature, these being marketing skills, financial skills, legal skills, conceptual skills, interpersonal skills and technical skills. One might ask why entrepreneurial skills have not been included here. As the study focuses on established businesses and not business start-up activities, entrepreneurial skills were not considered.

The interviews, as well as transcription of the interviews, were all done personally by the lead researcher. The transcripts incorporated notes and memos taken during the interview by the researcher. Interviews followed an interview guide, where the researcher discussed with the participant a range of themes relevant to the study. All interviews were recorded for the aim of future referral and data credibility.

Creswell's four-stage process of analysis for qualitative data was employed in this study (Creswell 2003):

- Step 1: Organise and prepare data: All data gathered were transcribed after every interview.

- Step 2: Read through all data: An initial pass was made through the data to gain an overall understanding of the views of Black small-enterprise owners with regard to the business- and management skills deemed to be essential for the longevity of a small enterprise. Data were grouped into themes, based on the views that emerged from the interviews.
- Step 3: Begin a detailed analysis with a coding process: Here, one needs to identify the themes that emanate from each interview. Care should be taken not to duplicate themes. Constant revision is needed of dimensions and properties in order to consider subthemes, new themes that arise or even the possibility of having to collapse two or more themes into one

- Step 4: Use coding process to generate descriptions: Data from the identified themes were unpacked by making connections between the themes (Neuman 2003). Themes are thus continually being developed, but this development extends beyond dimensions and properties (Strauss \& Corbin 1998) as it also entails linkages and relationships with other themes.

\section{Ethical considerations}

The authors adhered to ethical considerations and protected the participants' rights by informing them of their rights to voluntary consent and confidentiality (Cooper \& Schindler 2003). All participants received letters requesting them to participate in this study. The letter explained the reason for the interviews and how the interviews would be conducted. It also requested permission to record the interviews for the purpose of capturing all the information, much of which could have been missed when taking notes only. The letter stated that the recording would be used solely for the study, would be stored safely and would be destroyed once the study had been completed.

\section{Trustworthiness}

Four criteria are crucial in order for qualitative research to be of good quality, or trustworthy. These criteria are described below, as per Lincoln and Guba (1985).

\section{Credibility}

This study sought data from Black-owned small enterprises in Soweto. Observation was constant as the researcher was involved in all activities associated with data capture and data preservation.

\section{Transferability}

In this study, the intention was to examine the context of the Black-owned small enterprise in Soweto. Transferability therefore pertains to how accurately the findings can be extrapolated to other small enterprises. As such, these findings can be extrapolated to small enterprises in other regions as the study takes cognisance of the heterogeneity of small enterprises and their owners.

\section{Dependability}

Applying the research to the same or similar participants in the same or similar context(s) should produce similar results. Thus, if credibility is ensured, dependability should also be ensured. 


\section{Confirmability}

Recordings and transcripts leave an adequate trail regarding conclusions, interpretations and recommendations which can be traced to their source.

\section{Discussion}

Table 2 portrays some of the more salient aspects of the participants' demography. As can be seen from the data presented, the majority of the small-enterprise owners were male, had been conducting business for a period of between five and 10 years and were older than 50 years of age. This leads one to the conclusion that the participants had between them accumulated a wealth of experience and were thus in a good position to provide meaningful insights as to the business- and managerial skills of Black-owned small enterprises in Soweto.

Interviews started off with the researcher probing the participants' views on the importance of the business owner being in possession of six key business- and managerial skills when developing the enterprise, these being marketing-, financial-, legal-, conceptual-, interpersonal- and technical skills. The prevailing literature holds these to be cruciallyimportant skills for developing a business, hence the object of this questioning was to assess whether Black small-enterprise owners in Soweto echoed this sentiment.

\section{Important business skills}

It is important to note that the same questions were posed to all participants in an attempt to ascertain whether they viewed the particular skill as being an important one for developing a small enterprise, irrespective of whether or not they actually possessed that skill themselves. Many of the participants related their answers to what they were doing in their enterprises. Comments forthcoming from the interviews have been included as evidence of claims made. All responses were anonymous, as the only criterion for inclusion was the fact that they were small-retail Black business owners, and no other details were requested.

\section{Marketing skills}

The majority of the participants (15 of the 25 participants) stated that it was crucial for small-enterprise owners to possess marketing skills in terms of developing their

TABLE 2: Demographic data.

\begin{tabular}{lll}
\hline Variable & Demographic data & $N$ \\
\hline Gender & Male & 15 \\
& Female & 10 \\
Longevity of business & $5-10$ & 13 \\
& $11-15$ & 4 \\
& $16-20$ & 1 \\
Age & $20+$ & 7 \\
& $20-29$ & 0 \\
& $30-39$ & 7 \\
& $40-49$ & 8 \\
& $50+$ & 10 \\
\hline
\end{tabular}

enterprises. However, there was a minority sentiment that marketing skills were not essential skills to possess in developing the enterprise. Some of the sentiments expressed toward marketing skills include:

- 'Marketing helped improve sales and secured more customers'.

- 'It is important to incorporate after sales feedback and good customer service as a way of marketing'.

- 'We find it useful to use the Post office to deliver pamphlets to houses, this increases awareness of our business'.

- 'Community gatherings and stokvels [township savings clubs] are useful to advertise and attract customers'.

It must be noted that, in some instances, participants noted that although it is not crucial for an enterprise owner to possess marketing skills, they were of the opinion that the act of marketing is important to the enterprise. They felt that if the owner did not possess these skills, they could be outsourced.

\section{Financial skills}

Thirteen of the 25 participants stated that a business owner did not need to possess financial skills in order to develop their business, as this function (just as was the case with marketing) could be outsourced to bookkeepers and accountants. This is not to say they did not deem prudent financial management as being important, rather they felt that the business owner could entrust these tasks to a contracted party. One comment was especially striking in this regard:

- 'If you always go for money, you collapse. If I knew all the financial details of my bakery I would have given it all up, long ago. We were not profitable for four years, but my lack of awareness about the degree of financial strain helped me continue with this enterprise. My accountant took on the responsibility to turn the business around'.

Benefits cited by participants who possessed financial skills, mostly due to formal training, can be seen below:

- 'Financial skills have enabled me to use my discretion as to how to do costing and mark-up and what to invest'.

- 'Applying financial skills has helped to manage my finances without having to depend on a bookkeeper or an accountant'.

- 'A business does not always make a profit. Managing a business, especially the financial side of it, can be problematic if you don't know what is going on'.

\section{Legal skills}

Seventeen of the 25 participants were of the opinion that the business owner need not possess any legal skills in order to develop their business. As with financial skills, they felt that legal tasks and duties that need to be performed could be outsourced to lawyers and legal advisors. One of those who did possess legal skills commented, inter alia, as follows:

- 'Knowledge of the law helped in complying with the law by registering workers with the Department of Labour and deducting the Unemployment Insurance Fund'. 


\section{Conceptual skills}

The majority of the participants (16 of 25$)$ felt that it is crucial for a business owner to possess conceptual skills in order to develop their enterprises. Conversely, some business owners felt that conceptual skills had little value in terms of developing the enterprise and that they were a 'nice-to-have' and not a 'must-have' attribute. Business owners expressed the following regarding the benefits of conceptual skills:

- 'Conceptual skills have helped me to be an early starter and to attract customers before there was competition'.

- 'I am able to translate ideas into money makers'.

- 'Conceptual skills have contributed to efficient and profitable day-to-day running of the business and the capacity to deal with issues before they became a problem'.

\section{Interpersonal skills}

All participants felt that interpersonal skills were crucial for the development of a small enterprise. Amongst others, the participants mentioned the following interpersonal aspects as being cardinal for the development of their enterprises:

- Interacting with customers, suppliers and staff in an effective way.

- Solving conflicts.

- Acquiring customers through word of mouth and referrals.

- Going the extra mile for customers.

- Building positive relationships with customers and staff.

- Relating to people easily.

\section{Technical skills}

An overwhelming majority (23 of 25) of the participants felt that technical skills were a major contributing factor to the development of their enterprises. It was, however, interesting to note that one person expressed the sentiment that technical skills played no part in the development of the enterprise. The possibility cannot be excluded that this research subject might not have known what was meant by technical skills. The following comment reiterates the importance of technical skills:

- 'You must know what your product is all about. You need knowledge and technical skills with regard to the business'.

\section{Additional skills}

Participants were asked to reflect upon and identify additional skills that they deemed to be of importance for the development of a small enterprise. Many of the participants could not identify any factors further to those they had already been questioned on, but mentioned such traits such as passion, honesty, determination, consistency, patience, tenacity, hard work, prudence and motivation.

Those participants that did venture to identify other salient skills mentioned benchmarking skills, computer skills, creative skills and strategic skills. As benchmarking-, computer- and creative skills were identified by no more than one research subject, they cannot be deemed to be an important skill identified by Black small-enterprise owners as a whole.

Table 3 shows the degree of importance that the Black smallbusiness owners of Soweto placed on each of these attributes.

It would seem as though the more specialised the skill becomes, the more likely the business owner would be to outsource this skill if they have little formal training therein. This would also seem to imply that Black small-enterprise owners in Soweto differentiated between the possession of a crucial skill by the owner and the need for such a skill in the business. Furthermore, these findings also reveal that specialised business skills (e.g. financial and legal skills) are not present in abundance amongst the Black small-enterprise owners in Soweto.

\section{Key success factors}

Participants were asked what they viewed as being the most crucial aspect that has contributed to the success of their small enterprises. Opinion was varied and focused on important traits a business owner should possess, such as being hard working, hands-on, professional, punctual, focused and passionate. Few participants focused on skills, but marketing skills were reflected upon by some of the participants.

Few of the factors mentioned by the participants were mentioned more than once. However, 10 of the 25 participants viewed being passionate about their enterprise as being most crucial to them. Furthermore, seven of the subjects reflected that marketing was of the utmost importance to them. Here, sentiment reflected that being customer orientated was of singular importance to these enterprise owners. Being focused in terms of having a clear vision was another factor mentioned by two of the research participants.

The following excerpts from the interviews conducted support the claims above:

- 'They should realise that keeping the customer happy was more important than pursuing money. Mistakes should be rectified immediately'.

- 'You must be passionate about the type of business you want to start. Your heart should be in the business'.

- 'Dedication and having a clear focus has enabled me to be strong and withstand difficult times'.

- 'Be committed and do the job wholeheartedly. Don't be lazy'.

TABLE 3: Skills contribution as seen by owners.

\begin{tabular}{ll}
\hline Skill & $\begin{array}{l}\text { Number of participants viewing the skill as } \\
\text { contributing to the enterprise }(\boldsymbol{N}=\mathbf{2 5})\end{array}$ \\
\hline Interpersonal & 25 \\
Technical & 23 \\
Conceptual & 16 \\
Marketing & 15 \\
Financial & 12 \\
Legal & 7 \\
\hline
\end{tabular}


The findings suggest that these business owners viewed the key to success as emanating from the enterprise owner, implying an internal locus of control as far as success factors are concerned. Black business owners thus view key success factors as something firmly within their control and theirs to control.

\section{Advice for aspiring entrepreneurs}

When asked to reflect on advice they might have for aspiring Black business owners, the participants reiterated issues such as understanding what the customer wants, being passionate about the business, being knowledgeable about their products and services and being dedicated and focused. Most of these sentiments were views that had been expressed previously. However, two participants did touch on the aspect of competitive advantage. These participants mentioned that it is crucial for aspiring business owners to set themselves apart from other businesses. The following quotations bear witness to this sentiment:

- 'You need something new and different that describes you and your business'.

- 'Have something that belongs to you only'.

It seems strange that the concept of competitive advantage had not been alluded to more frequently by participants and that it was not mentioned as a key success factor by any of them. One could speculate that, at face value, the research suggests that the concept of competitive advantage is either overlooked or poorly understood by the participants. This is an interesting finding, as contemporary strategicmanagement literature suggests that competitive advantage is probably the single-most pivotal factor in the success of a business. In this case, it might also be that the concept is not necessarily ignored, but might be conceptualised differently by Black small-enterprise owners in Soweto.

\section{Identified areas of improvement}

Participants were also asked to reflect on things they felt they should have done differently in their enterprises. Five of the participants felt that there was nothing that they would have done differently and a further five participants did not respond to this question, even after constant probing. This might indicate that there were things that they felt could change, but they were not exactly sure what these things were. From those participants that did reflect on things they would have done differently, opinions tended to reflect a few pertinent sentiments. Five of the participants reflected that they would search wider for funding for the business. A few aspects were mentioned by two participants, namely, the acquisition of, and training in, tax-related matters; the feeling that they should have employed more trustworthy staff; that they should have taken more risks; and that they should have taken better advantage of formal education and training opportunities, especially in terms of finances.

It would seem as though most of the regrets experienced by small-enterprise owners were related to financial matters, implying that the importance of possessing financial skills only becomes apparent after the enterprise has been established. The following interview excerpts reflect the above sentiments:

- 'I should have left my previous job earlier ... and not feared the unknown'.

- 'Take schooling seriously and know what you want to be'.

- 'I think I should get some training of tax'.

- 'Do research, draw up a business plan and get funding'.

- 'Don't be too trusting of people ... even your staff. Remember, they don't have the same idea you have'.

\section{Outstanding moments and/or experiences}

The participants were asked to reflect on events, experiences or situations that made all their hard work as enterprise owners worthwhile. All of the small-enterprise owners could recall moments that embodied success and achievement for them.

By far the largest sentiment echoed here, from 11 of the 25 participants, revolved around the owner experiencing how the business grew to achieve good standing or success from a market point of view, to which the following quotations bear witness:

- 'Moving from working in a backyard shack to an industrial park and subcontracting for Eskom'.

- 'Growing from selling fish and chips and sorghum beer to a buy-and-braai licensed entertainment and eating outlet'.

- 'Seeing the restaurant fully booked and customers waiting to get a table'.

Further to this sentiment, four of the participants were recipients of awards, namely, Shoprite Woman of the Year 2008, SAB Young Entrepreneur, Best Bed \& Breakfast in Soweto 2004-2008 and finalist at Business Women Association Entrepreneur of the Year 2009.

Three research subjects cited recognition as FIFA's 2010 Accommodation of Choice as being an outstanding moment and a further two reflected that reaching their first R1 million in turnover was a proud moment for them.

It is interesting to note that these sentiments reflect mainly non-monetary rewards for the enterprise owners. None of the participants reflected on making money out of the business as being an outstanding moment or achievement. This seems to be indicative of a mindset where profit is not the motivator for establishing a business, but rather that the attainment of an ideal is what provides purpose to the small enterprise owner.

\section{Recommendations and managerial implications}

Before recommendations and managerial implications are presented, it might be prudent to summarise the most salient findings and conclusions forthcoming from the study:

- Most enterprise owners lack business skills such as financial skills and legal skills. 
- Most enterprise owners benefit from management skills such as conceptual skills, interpersonal skills and technical skills.

- Participants differentiated between skills needed by the business owner as opposed to skills needed by the enterprise owners.

- Passion and customer focus seemed to be factors that most small-enterprise owners deemed to be crucial for the success of the enterprise.

- Black small-enterprise owners in Soweto deemed key success factors to be factors they had exclusive control over.

- Regrets experienced by small-enterprise owners are mostly related to financial issues.

- The concept of competitive advantage seems, to a large extent, to be overlooked or understood poorly by smallenterprise owners.

- Small-enterprise owners seem to be driven by nonmonetary rewards when reflecting upon defining moments in the business.

As this study aimed to assess which skills Black smallenterprise owners in Soweto possess and which skills have contributed to the success of their enterprises, it would be logical to compare the findings resultant from this study with perspectives from literature. Papulová and Mokroš (2007) contend that most small enterprises do not survive because of a lack of business- and managerial skills. This study does seem to confirm this sentiment, but makes a clear distinction between the skill being present in the business as opposed to the particular skill being innate to the business owner. Many of the participants admitted openly that they do not possess certain skills that the literature views as crucial, but these participants also recognised that the skills are important to the business. Hence, where business owners themselves do not possess a skill, it is outsourced.

Dockel and Ligthelm (2005) contend that although literature suggests skills that appear to be key factors, they are not the only key factors for business success. This is echoed by the findings of this study, especially where participants were asked to reflect on additional skills they viewed as being important to the development of an enterprise or where participants were asked to identify key success factors of their enterprise. Therefore, one has to conclude that longevity of a small enterprise is dependent on a range of variables, ranging from personal characteristics and traits to situational factors and unique skills, which seem to reflect the sentiments of Jayawarna and MacPherson (2006). The study therefore also underscores the importance of a contextualised approach toward studying the modern business organisation, irrespective of scope.

The study also suggests that strategic concepts, such as competitive advantage, are either overlooked or understood poorly by Black small-enterprise owners in Soweto. However, this conclusion is reached when considering strategy from a typically Anglo-Saxon view of the large firm. In a study by Thompson, Bounds and Goldman (2012), it was found that many successful small-, medium- and micro-sized enterprises (SMME) owners or managers did not conduct strategic management in the classical concept of the term. However, many of these SMME owners or managers did exhibit elements of thinking strategically. Through this, Thompson et al. (2012) concluded that SMME owners or managers cannot be seen as being ignorant of strategic management, but rather conceptualise and practise strategic management differently when compared with corporate enterprises. The findings of this study suggest the same thing. This is definitely an area that needs attention, not only in terms of curriculum development and training for existing business owners, but in the need for a shift of emphasis. It is becoming apparent that strategic management seems to be conducted according to a different set of rules in SMMEs versus corporate enterprises. Energy needs to be channelled into discovering what strategy and strategic management is all about in the SMME context.

It is interesting to note that all of the Black small-enterprise owners who formed part of this study described defining moments in the existence of their enterprises in nonmonetary terms. What was very prominent was that serving their communities and being recognised in their respective communities seemed to be strong driving forces.

This sentiment alludes to the role of the business organisation in society. The traditional, western capitalist thought surrounding the business organisation is that it exists in order to make a profit. This study indicates a uniquely-African perspective on the business organisation as a role-player in society. It views the enterprise as being part of society and not apart from society, tapping into the African collective value system. This view is crucial when it comes to creating a sense of economic development through community. In a country where the creation of small business is seen as a pivotal step in boosting and expanding the economy, it could be a useful strategy to highlight the role that traditional, African values can play in the establishment of SMMEs and how this is linked to economic development.

\section{Limitations of the study}

One would have to broaden this study to different localities in order to establish a more complete profile of the Black South African small-enterprise owner. The study is exploratory and utilised qualitative methods. Although this in itself is not a limitation, it is important to realise that the outcome of this study is not absolute. If irrefutable proof is sought of the claims made in this study, one would have to test or prove them through the use of quantitative methodologies.

\section{Conclusion}

This study did not actually show that Black-owned small enterprises in Soweto are different from any other small enterprise in South Africa. What it has highlighted, however, are more important aspects. In the study of the business organisation as a study object, this research makes it very 
clear that concepts should be investigated differently between enterprises of differing scope (SMMEs versus corporate enterprise). This study makes one aware that in Africa, one needs to be aware of 'the African way', as this even extends further than one might think. It also extends into the very fibre of SMMEs. In fact, it is these very African values that helped form the foundation for the King I, II and III reports on corporate governance.

\section{Acknowledgments Competing interests}

The authors declare that they have no financial or personal relationships which may have inappropriately influenced them in writing this article.

\section{Authors' contributions}

E.Y.N. (University of Johannesburg) conducted the research as an M. Com Business Management student, with M.M.B. (University of Johannesburg) as supervisor. The manuscript was drafted by E.Y.N. G.G. (University of Johannesburg) and M.M.B. reworked the manuscript into its final form.

\section{References}

Abor, J. \& Quartey, P., 2010, 'Issues in SME development in Ghana and South Africa', International Research Journal of Finance and Economics 39, 218-239.

Babbie, E. \& Mouton, J., 2004, The practice of social research, Oxford University Press, Cape Town.

Bateman, T. \& Snell, S., 2009, Management: Leading and collaborating in a competitive world, McGraw-Hill, Boston.

Beins, B., 2009, Research methods: A tool for life, Pearson, Boston.

Bekele, E. \& Worku, Z., 2008, 'Factors that affect the long-term survival of micro, small and medium enterprises in Ethiopia', South African Journal of Economics 76(3), 548-568. http://dx.doi.org/10.1111/j.1813-6982.2008.00207.x

Bless, C., Higson-Smith, C. \& Kagee, A., 2006, Fundamentals of social research methods: An African perspective, Juta, Cape Town.

Bodla, B.S. \& Verma, S.R., 2008, 'An analysis of the performance of SSIs in the era of globalization', The IUP Journal of Managerial Economics 6(3), 40-53.

Burgess, C., 2007, 'Do hotel managers have sufficient financial skills to help them manage their areas?', International Journal of Contemporary Hospitality Management 19(3), 188-200. http://dx.doi.org/10.1108/09596110710739895

Collis, J. \& Jarvis, R., 2002, 'Financial information and the management of smal private companies', Journal of Small Business and Enterprise Development 9(2), 100-110. http://dx.doi.org/10.1108/14626000210427357

Cooper, E.R. \& Schindler, P.S., 2009, Business research methods, 8th edn., McGraw Hill, New York.

Creswell, J.W., 2003, Research design: Qualitative, quantitative and mixed approaches, Sage, Thousand Oaks.

Davis, D. \& Woodward, B., 2009, 'An analysis of skills required of graduates of an Information Systems program', Information Technology, Learning and Performance Journal 24(2), 11-21.

Dockel, J.A. \& Ligthelm, A.A., 2005, 'Factors responsible for the growth of small businesses: management', South African Journal of Economic and Management Sciences 8(1), 54-62.

Egbu, C.O., Hari, S. \& Renukappa, S.H., 2005, 'Knowledge management for sustainable competitiveness in small and medium surveying practices', Structural Survey 23(1), 7-21. http://dx.doi.org/10.1108/02630800510586871

Foreman-Peck, J., Makepeace, G. \& Morgan, B., 2006, 'Growth and profitability of small and medium sized enterprises: Some Welsh evidence', Regional Studies 40(4), 307-319. http://dx.doi.org/10.1080/00343400600725160

Giliomee, J., 2004, The small business environment, Entrepreneurial Business School, Bellville.

Gloy, B.A. \& LaDue, E.L., 2003, 'Financial management practices and farm profitability', Agricultural Finance Review 63(2), 157-174. http://dx.doi. org/10.1108/00215060380001147
Hatten, T., 2009, Small business management: Entrepreneurship and beyond, South Western, Mason.

Jayawarna, D. \& MacPherson, A., 2006, 'Managers' perceptions of management development needs in manufacturing SMEs', Education \& Training 48(8/9), 666681. http://dx.doi.org/10.1108/00400910610710083

Kotey, B. \& Folker, C., 2007, 'Employee training in SMEs: Effect of size and firm type - Family and nonfamily', Journal of Small Business Management 45(2), 214-238.

Lee, G. \& McGuiggan, R., 2008, 'Understanding small- and medium-sized firms' financial skill needs', Journal of International Finance and Economics 8(3), 93-103.

Ligthelm, A.A., 2008, 'A targeted approach to informal business development: the entrepreneurial route', Development Southern Africa 25(4), 367-382. http:// dx.doi.org/10.1080/03768350802316138

Ligthelm, A.A., 2009, Small business dynamics in Soweto: A longitudinal analysis, UNISA Bureau of Market Research, Pretoria.

Lincoln, Y.S. \& Guba, E.G., 1985, Naturalistic Inquiry, Sage, Newbury Park.

Marx, S., Van Rooyen, D. \& Reynerder, H., 1998, Business management, Van Schaik, Pretoria.

Meggison, L., Byrd, M. \& Meggison, W., 2006, Small business management: An entrepreneur's guide, McGraw-Hill, Singapore. PMid:17032143

Miller, R.L. \& Brewer, J.D., 2003, The A-Z of Social Research. A Dictionary of Key Socia Science Research Concepts, Sage, London.

Moodie, G., 2003, 'Education is the missing link', Sunday Times Business Times, 30 March, p. 1.

Needle, D., 2004, Business in context: An introduction to business and its environment Thomson, London.

Neuman, W.L., 2003, Social Research Methods: Qualitative and quantitative approaches, Allyn \& Bacon, Boston.

Nieman, G., 2006, Small business management: A South African approach, Van Schaik, Pretoria.

Nieman, G. \& Bennett, A., 2006, Business management: A value chain approach, Van Schaik, Pretoria.

Nieuwenhuizen, C., 2008, Entrepreneurial skills, Juta, Cape Town. PMCid:PMC2292985

Northouse, P., 2009, Introduction to leadership: Concepts and practice, Sage, Thousand Oaks. PMCid:PMC3244754

Oosthuizen, J.H. \& Van Tonder, E., 2010, 'An exploratory study of the critical managerial skills-set for formal sector venture success in townships and managerial skills-set for formal sector venture success in townships and
disadvantaged communities', in E. Njiro \& T. Mazwai (eds.). Transforming disadvantaged communities', in E. Njiro \& T. Mazwai (eds.), Transforming townships into economic powerhouse: 2010 Soweto International Conference
on Entrepreneurship \& Development: proceedings, Soweto, South Africa, 27-28 on Entrepreneurship \& De
January 2010, pp. 81-106.

Papulová, Z. \& Mokroš, M., 2007, 'Importance of managerial skills and knowledge in management for small entrepreneurs', in D.K. Hsu (ed.), E-Leader conference: proceedings, Prague, Czech Republic, 11-13 June 2007, pp. 1-8.

Parmigiani, A. \& Mitchell, W., 2010, 'The hollow corporation revisited: Can governance mechanisms substitute for technical expertise in managing buyersupplier relationships?', European Management Review 7(1), 46-70. http:// supplier relationships?', European
dx.doi.org/10.1057/emr.2009.28

Pettinger, R., 2007, Introduction to management, Palgrave-McMillan, New York. PMCid:PMC2670850

Robbins, R. \& Hunsaker, P., 2006, Training in interpersonal skills: Tips for managing people at work, Prentice-Hall, Upper Saddle River.

Roodt, J., 2005, 'Self-employment and the required skills', Management Dynamics 14(4), 18-33.

SME Development Council of Malaysia, 2010, SME annual report 2009/2010, National SME Development Council, Kuala-Lumpur.

Strydom, J.W., 2005, 'Tracking study on skills development and employment generation of small retail establishments in Mamelodi, Tshwane', Southern African Business Review 9(3), 15-22.

Strauss, A. \& Corbin, J., 1998, Basics of qualitative research: Techniques and procedures for developing Grounded theory, Sage, London.

Tambunan, T., 2007, 'Entrepreneurship development: SMEs in Indonesia', Journa of Development Entrepreneurship 12(1), 95-118. http://dx.doi.org/10.1142/ S1084946707000575

Thompson, C., Bounds, M. \& Goldman, G.A., 2012, 'The status of strategic planning in small and medium enterprises: or afterthought?', South African Journal of Entrepreneurship and Small Business Management 5(1), 33-52.

Tuan, N.P. \& Yoshi, T., 2009, 'Factors contributing to the growth of small and medium enterprises: An empirical analysis of Vietnam's manufacturing firms', singapore Management Review 31(2), 35-51.

Van Eeden, S., Viviers, S. \& Venter, D., 2003, 'A comparative study of selected problems encountered by small business in the Nelson Mandela, Cape Town and Egoli Metropoles', Management Dynamics 12(3), 12-22.

Van Rensburg, L., 2008, Business Management: An Introduction, Van Schaik, Pretoria. Walliman, N.S.R., 2006, Social research methods, Sage, London.

Zikmund, W.G., 2009, Business research methods, South-Western, Mason. 